\title{
An Analysis of the Environmental Impact Management of Tingal Irrigation Scheme in Temanggung Regency
}

\author{
Widodo Brontowiyono \\ Universitas Islam Indonesia, Yogyakarta, Indonesia. \\ Email: widodo.bronto@uii.ac.id
}

\begin{abstract}
A study of the environmental impacts of Tingal Irrigation Scheme should be conducted to derive maximum benefits from the project development and management. This research aimed to identify the pre-existing environmental conditions, describe the expected potential impacts, and recommend some methods to manage and monitor the impacts. The analysis results indicated that the pre-existing environmental conditions of the study area were generally good, different types of impacts potentially arose from each stage of the development, and each type of impacts required specific, detailed management and monitoring.
\end{abstract}

Keywords: Development, Impact, Environmental Management, Monitoring.

\section{A. INTRODUCTION}

Agricultural activities play a strategic role and function for an agrarian society in which a majority of the population relies on the agricultural sector to meet their daily needs (Tayibi, Choura Lopez \& Alguacil, 2009). Consequently, irrigated land holds not only economic values but also philosophically religious values which is central to the society. To maintain and optimize agricultural land, sufficient infrastructure is required and utilization of natural resources should adopt the concept of environmental balance and modern management (Tiwary, 2001).

The irrigation network in Tingal Irrigation Scheme mainly consists of natural channels utilized by farmers to flow water from natural drainage systems. The irrigation network is irregularly used and damaged, with sedimentation found along the channels as well as incomplete irrigation structures, thereby preventing it from functioning properly (Gomiero, Pimentel \& Paolewtti, 2011). This condition therefore requires optimum development.

The environmental impacts of Tingal Irrigation Scheme development activities should be analyzed due to the increasing number of issues related to the natural resources management ( $\mathrm{Li}$, Liu, Leamon \& Chen, 2017). In addition, to maximize the benefits of the development and management of Tingal Irrigation Scheme, an environmental feasibility study should be conducted to examine both the potentially beneficial and adverse impacts on the society (Franks \& Vanclay, 2013).

This study aims to: 1) identify the pre-existing environmental conditions prior to the development of Tingal Irrigation Scheme; 2) clearly identify the potential 
impacts of the development of Tingal Irrigation Scheme; and 3) recommend a number of methods to manage and monitor the potential impacts.

\section{B. LITERATURE REVIEW}

Environmental management is defined as a conscious effort to maintain and or improve the quality of the environment to meet basic human needs at its best. It is an integrated effort in the utilization, planning, maintenance, monitoring, control, restoration, and development of the environment (Manik, 2003).

Environmental management planning for a development project is generally done by taking into account the potential impacts of the project (Yadav \& Samaddeer, 2018). The methods of environmental management planning are referred to as Environmental Impact Assessment (Kaplan \& Bannett, 2018). Such analysis is a means of examining the feasibility of a project plan from an environmental perspective (Soemarwoto, 2004).

Indonesia has issued and enforced Law No. 32/2009 on Environmental Protection and Management as well as its related regulations. A development proponent is obligated to perform the analysis and prepare the documents with reference to the level of impacts outlined in the regulation. The analysis is prepared in environmental documents which contain AMDAL (Environmental Impact Assessment), DELH (Environmental Evaluation Document), UKL-UPL (Environmental Management Efforts - Environmental Monitoring Efforts), or SPPL (Statement of Environmental Management and Monitoring Undertaking).

\section{METHOD}

\section{Data Collection Methods}

Secondary Data Collection. The secondary data was collected from a number of previous studies, analyses, and reports as well as from the reports provided by the related agencies and applicable regional regulations. This method included a literature study and institutional analysis.

Data Collection through Observation and Field Survey. The data collected by this method mainly consisted of social environment components (demography, economy, culture, and public health). The technique to obtain the data involved a questionnaire survey (Deus, Mele, Bezerra \& Battistelle, 2020).

Using the purposive random sampling, the quota for one subdistrict was 30 respondents, thereby totaling 60 respondents for the study. The required sample size for a simple statistical analysis in cross-tabulation is a minimum of 20 respondents.

Data Collection through Observation and Measurement. The field survey/observation resulted in primary data consisting of the components of the environment that were potentially affected by the project, namely the physicochemical, socioeconomic and cultural, biological, and public health conditions to be analyzed (Amato, Rocchetti \& Beolchini, 2017). The data described the environmental conditions during the field study. The air quality and noise level were assessed at two points of observation: 1) in front of SDN 1 Sanggrahan, 
Kranggan Subdistrict, Temanggung Regency as part of Tingal Kiri (left) Irrigation Scheme, and 2) in front of the Office of Geblog Village, Kaloran Subdistrict, Temanggung Regency as part of Tingal Kanan (right) Irrigation Scheme.

Meanwhile, the water quality was measured at two sites: 1) Mandang River as part of Tingal Kiri Irrigation Scheme, and 2) Mereng River as part of Tingal Kanan Irrigation Scheme.

\section{Data Analysis Methods}

Analysis of Physicochemical Conditions: 1) Water quality. The analysis methods and equipment for river water samples referred to the Government Regulation No. 82/2001 on Water Quality Management and Water Pollution Control for Class II Waters. The parameters and quality standards also referred to this regulation; 2) Air Quality and Noise Level. The analysis methods in the laboratory and the equipment for air samples referred to the Government Regulation No. 41/1999 on Air Pollution Control. The noise data was analyzed based on the noise level per time-interval (Leq), day noise level (LS), night noise level (LM), and daynight noise level (LSM). The formulas referred to the Decree of the State Minister for the Environment Number Kep-48/MNLH/11/1996; 3) Analysis of Socioeconomic and Cultural Conditions. The methods were adjusted to the type of data to be analyzed, i.e. quantitative analysis for numerical data and qualitative analysis for perceptions, residents' income, and prevailing values in the society; 4) Analysis of Public Health Conditions (Al-Rumaihi, McKay \& Al-Anshari, 2020). Data on public health was analyzed using the environmental health impact assessment, including (1) simple statistics, (2) descriptive evaluative analysis, and (3) formal guidelines, in accordance with the significance (Palmeiri, Forleo, Giannoccaro \& Suardi, 2017). The data analyzed consisted of environmental sanitation, patterns of disease, and public health services. The data was presented in a frequency table.

The environmental management and impact analysis was performed by analogy with the preparation of environmental documents by referring to the Regulation of the State Minister for the Environment No. 16/2012 on Guidelines for the Preparation of Environmental Documents.

\section{RESULTS AND DISCUSSION}

Tingal Irrigation Scheme is situated in Kaloran Subdistrict (Villages: Geblog and Gandon) and Kranggan Subdistrict (Villages: Kemloko, Klepu, Sanggrahan, and Pendowo) of Temanggung Regency. This Irrigation Scheme lies on the Tingal River which covers $62,614 \mathrm{~km} 2$ area of Tingal Watershed.

The area surrounding Tingal Irrigation Scheme has a temperature of 18 $30^{\circ} \mathrm{C}$, with potentially high rainfall reaching approximately $2750-3250 \mathrm{~mm} /$ year. Temanggung Regency has a tropical climate with two alternating seasons throughout the year, the rainy season and the dry season (BMKG, 2018). The air quality and noise level are shown in Table 1. No parameters exceed the quality 
standards at the two sampling locations, thus indicating good air quality and noisefree area.

Table 1. Air Quality and Noise Level around Tingal Irrigation Scheme

\begin{tabular}{|c|l|c|c|c|c|c|}
\hline \multirow{2}{*}{ No } & \multirow{2}{*}{ Parameter } & Unit & Method/Equipment & \multirow{2}{*}{$\begin{array}{c}\text { Quality } \\
\text { Standard }\end{array}$} & \multicolumn{2}{|c|}{ Analysis Result } \\
\cline { 6 - 7 } & & & Point 1 & Point 2 \\
\hline 1 & $\mathrm{NO}_{2}{ }^{*}$ & $\mu \mathrm{g} / \mathrm{Nm}^{3}$ & SNI 7119.2-2017 & 316 & 32.36 & 26.14 \\
\hline 2 & $\mathrm{SO}_{2}{ }^{*}$ & $\mu \mathrm{g} / \mathrm{Nm}^{3}$ & SNI 7119.7-2017 & 632 & 115.54 & 100.21 \\
\hline 3 & $\mathrm{CO}$ & $\mu \mathrm{g} / \mathrm{Nm}^{3}$ & $\begin{array}{c}\text { SNI 7119.10-2011 } \\
\text { Spectrophotometer }\end{array}$ & 15,000 & $1,285.81$ & $1,196.55$ \\
\hline 4 & $\mathrm{TSP}^{*}$ & $\mu \mathrm{g} / \mathrm{Nm}^{3}$ & SNI 7119.3-2017 & 230 & 144.78 & 130.51 \\
\hline 5 & & $\begin{array}{c}\mathrm{dBA} \\
\left(\mathrm{L}^{\mathrm{eq}}\right)\end{array}$ & $\begin{array}{c}\text { SNI 8427-2017 } \\
\text { (Sound Level Meter) }\end{array}$ & 70 & 59.4 & 48.1 \\
\hline
\end{tabular}

Source: Primary Data (2020)

Note: *KAN accredited parameter (ISO/IEC 17025)

Point 1 = in front of SDN 1 Sanggrahan; Point $2=$ in front of the Office of Geblog Village. The water quality is shown in Table 2. The parameters and quality standards referred to the Government Regulation No. 82/2001 on Class II Waters.

Table 2. Water Quality in Tingal Irrigation Scheme

\begin{tabular}{|c|c|c|c|c|c|c|}
\hline \multirow{2}{*}{ No } & \multirow{2}{*}{ Parameter } & \multirow{2}{*}{ Unit } & \multirow{2}{*}{ Method } & \multirow{2}{*}{$\begin{array}{c}\text { Quality } \\
\text { Standard } \\
\text { for Class II } \\
\text { Waters }\end{array}$} & \multicolumn{2}{|c|}{ Test Result } \\
\hline & & & & & Site 1 & Site 2 \\
\hline & Physical & & & & & \\
\hline 1 & Dissolved solids* & $\mathrm{mg} / \mathrm{L}$ & SNI $06-6989.27$ - 2005 & 1000 & 284 & 608 \\
\hline \multirow[t]{2}{*}{2} & Suspended solids* & $\mathrm{mg} / \mathrm{L}$ & SNI $06-6989.3-2004$ & 50 & 16 & 22 \\
\hline & Inorganic Chemical & & & & & \\
\hline 3 & $\mathrm{pH}^{*}$ & - & SNI 06 - 6989.11 - 2004 & $6-9$ & 6.97 & 6.81 \\
\hline 4 & $\mathrm{BOD}^{*}$ & $\mathrm{mg} / \mathrm{L}$ & SNI 6989.72 : 2009 & 3 & 3.99 & 3.34 \\
\hline 5 & $\mathrm{COD}^{*}$ & $\mathrm{mg} / \mathrm{L}$ & SNI 6989.2 : 2009 & 25 & 24.76 & 24.76 \\
\hline 6 & $\mathrm{DO}^{*}$ & $\mathrm{mg} / \mathrm{L}$ & SNI 06 - 6989.14 - 2004 & 4 & 4.61 & 4.78 \\
\hline 7 & $\begin{array}{l}\text { Total Phosphate as } \\
\mathrm{P}\end{array}$ & $\mathrm{mg} / \mathrm{L}$ & SNI $06-6989.31$ - 2005 & 0.2 & 0.09 & 0.10 \\
\hline 8 & Nitrate & $\mathrm{mg} / \mathrm{L}$ & SNI 06 - 2480 - 1991 & 10 & 5.02 & 3.95 \\
\hline 9 & Ammonia* & $\mathrm{mg} / \mathrm{L}$ & SNI $06-6989.30-2005$ & $(-)$ & $<0.012$ & $<0.012$ \\
\hline 10 & Iron* & $\mathrm{mg} / \mathrm{L}$ & SNI $6989.4: 2009$ & $(-)$ & 0.195 & 0.185 \\
\hline 11 & Nitrite $^{*}$ & $\mathrm{mg} / \mathrm{L}$ & SNI 06 - 6989.9 : 2004 & 0.06 & 0.03 & 0.03 \\
\hline \multirow[t]{2}{*}{12} & Sulfate* & $\mathrm{mg} / \mathrm{L}$ & SNI $6989.20: 2009$ & $(-)$ & 3.00 & 3.19 \\
\hline & Organic Chemical & & & & & \\
\hline 13 & Oil and fat & $\mu \mathrm{g} / \mathrm{L}$ & SNI $06-6989.10-2004$ & 1000 & 410 & 470 \\
\hline \multirow[t]{2}{*}{14} & Detergent/MBAS & $\mu \mathrm{g} / \mathrm{L}$ & SNI $06-6989.51-2005$ & 200 & 56 & 58 \\
\hline & Microbiological & & & & & \\
\hline 15 & Total coliform & $\begin{array}{c}\mathrm{MPN} / 100 \\
\mathrm{~mL}\end{array}$ & MPN & 5000 & 880 & 980 \\
\hline
\end{tabular}

Source: Primary Data (2020) 
Note: *) KAN accredited parameter (ISO/IEC 17025)

(-) Parameter not required for this class

Table 2 shows a parameter that does not meet the quality standard that is BOD. The value of BOD exceeds the quality standard which is estimated to be caused by the high frequency of domestic activities nearby the water bodies into which the residents dispose washing and bathing wastewater (Yilmaz, Kara \& Yetis, 2017). This indicates non-optimal conservation in the upstream.

Meanwhile, among the conditions that can describe social dynamics is safety and convenience. All of the respondents (100\%) assessed the environment in which they reside as safe and comfortable. All of them (100\%) also stated that the relationship among the residents in the study area is excellent and harmonious.

In addition, the public health conditions in terms of sanitation for bathing, washing, toilet (MCK) showed that most of the respondents use well water (38 residents or $54.29 \%$ ). Meanwhile, 6 residents $(8.57 \%)$ use PDAM (pipe water) tap water (state-owned water utility company), and the remaining 26 residents $(37.14 \%)$ use other sources. Similarly, the majority of the respondents (41 residents or $58.57 \%$ ) use well water for drinking and cooking, followed by 6 residents (8.57\%) using PDAM water, and 1 resident $(1.43 \%)$ purchasing mineral water while the remaining participants use other sources.

The availability and quality of toilets also affect public health. All respondents have a toilet in their home. The majority of them $(84.29 \%)$ also have a septic tank for the toilet. Meanwhile, the most common types of disease from which the residents suffered are the flu, cold, and fever (50 respondents or $71.43 \%$ ). Five respondents (7.14\%) once had skin conditions, and 15 respondents $(21.43 \%)$ suffered from other disease types.

The development of Tingal Irrigation Scheme potentially has both positive and negative impacts on the environment. Despite the insignificant potential impacts, efforts should be made to manage and monitor the environment. The environmental impacts are estimated to occur during the pre-construction, construction, and operation stages. The potential impacts of the development of Tingal Irrigation Scheme are presented in Table 3.

Table 3. Potential Impacts of Tingal Irrigation Scheme

\begin{tabular}{|c|c|c|c|}
\hline $\begin{array}{c}\text { Developmen } \\
\text { t stage }\end{array}$ & Activity & $\begin{array}{c}\text { Type of } \\
\text { impact }\end{array}$ & Impact significance \\
\hline construction & $\begin{array}{c}\text { 1. Planning, survey, } \\
\text { and measurement }\end{array}$ & $\begin{array}{c}\text { Public } \\
\text { perception and } \\
\text { attitude }\end{array}$ & $\begin{array}{c}\text { The attitude of a majority of the } \\
\text { society members was in } \\
\text { accordance with the activity plan. }\end{array}$ \\
\hline Construction & $\begin{array}{c}\text { 2. Dissemination and } \\
\text { land acquisition } \\
\text { 1. Recruitment of } \\
\text { construction } \\
\text { porkers } \\
\text { the society }\end{array}$ & $\begin{array}{c}\text { Job } \\
\text { opportunities } \\
\text { and business } \\
\text { opportunities }\end{array}$ & $\begin{array}{c}\text { The attitude of a majority of the } \\
\text { society members was in } \\
\text { accordance with the activity plan. }\end{array}$ \\
\hline involved in the development \\
activities.
\end{tabular}




\begin{tabular}{|c|c|c|c|}
\hline $\begin{array}{l}\text { Developmen } \\
\text { t stage }\end{array}$ & Activity & $\begin{array}{l}\text { Type of } \\
\text { impact }\end{array}$ & Impact significance \\
\hline & & Social envy & $\begin{array}{l}\text { Some of the workers from the } \\
\text { neighboring village felt } \\
\text { unsatisfied and went on strike. }\end{array}$ \\
\hline & $\begin{array}{l}\text { 2. Construction and } \\
\text { operation of } \\
\text { basecamp }\end{array}$ & $\begin{array}{l}\text { Public } \\
\text { perception and } \\
\text { attitude }\end{array}$ & $\begin{array}{l}\text { There was a social conflict } \\
\text { between the society members and } \\
\text { migrant workers who stayed in } \\
\text { the basecamp. }\end{array}$ \\
\hline & & $\begin{array}{c}\text { Poor } \\
\text { environmental } \\
\text { sanitation }\end{array}$ & $\begin{array}{l}\text { The construction workers had a } \\
\text { lack of awareness of the } \\
\text { environmental sanitation in the } \\
\text { project area. }\end{array}$ \\
\hline & $\begin{array}{l}\text { 3. Mobilization of } \\
\text { equipment and } \\
\text { materials }\end{array}$ & $\begin{array}{l}\text { Higher levels } \\
\text { of dust } \\
\text { deposits and } \\
\text { exhaust gases }\end{array}$ & $\begin{array}{l}\text { The level of dust deposits was } \\
\leq 230 \mu \mathrm{g} / \mathrm{m}^{3} \text { and the level of } \\
\text { exhaust gases exceeded the } \\
\text { quality standard in the project } \\
\text { area and settlement area during } \\
\text { the project construction. }\end{array}$ \\
\hline & & $\begin{array}{c}\text { Damaged } \\
\text { access roads }\end{array}$ & $\begin{array}{c}\text { The types of road damage } \\
\text { included grade depression, } \\
\text { potholes, and mud-covered } \\
\text { slippery roads. }\end{array}$ \\
\hline & & Public concern & $\begin{array}{l}\text { Some residents blocked the access } \\
\text { routes/roads to the mobilization } \\
\text { of vehicles. }\end{array}$ \\
\hline & 4. Land development & $\begin{array}{l}\text { Land-use } \\
\text { change }\end{array}$ & $\begin{array}{l}\text { Vegetated land was converted } \\
\quad \text { into open land. } \\
\text { Wildlife habitat was disrupted. }\end{array}$ \\
\hline & & $\begin{array}{l}\text { Disruption of } \\
\text { wildlife } \\
\text { habitat }\end{array}$ & $\begin{array}{l}\text { There was wildlife-habitat } \\
\text { destruction or loss. }\end{array}$ \\
\hline & $\begin{array}{l}\text { 5. Development } \\
\text { activities }\end{array}$ & $\begin{array}{c}\text { Potential } \\
\text { occupational } \\
\text { accidents and } \\
\text { diseases } \\
\end{array}$ & $\begin{array}{c}\text { Construction workers } \\
\text { experienced occupational } \\
\text { accidents and diseases during the } \\
\text { project. }\end{array}$ \\
\hline \multirow[t]{3}{*}{ Operation } & $\begin{array}{l}\text { 1. Utilization of } \\
\text { irrigation network }\end{array}$ & $\begin{array}{c}\text { Poor } \\
\text { environmental } \\
\text { sanitation }\end{array}$ & $\begin{array}{l}\text { Canal cleanliness decreased and } \\
\text { water pollution increased. }\end{array}$ \\
\hline & & $\begin{array}{l}\text { Increased } \\
\text { population of } \\
\text { aquatic biota }\end{array}$ & $\begin{array}{c}\text { There was a balanced ecosystem } \\
\text { for aquatic biota marked by the } \\
\text { higher zooplankton diversity } \\
\text { index. }\end{array}$ \\
\hline & & $\begin{array}{c}\text { Increased } \\
\text { population of } \\
\text { flora }\end{array}$ & $\begin{array}{l}\text { Numerous vegetation/plants } \\
\text { could grow well in the irrigation } \\
\text { network area. }\end{array}$ \\
\hline
\end{tabular}




\begin{tabular}{|c|c|c|c|}
\hline $\begin{array}{l}\text { Developmen } \\
\text { t stage }\end{array}$ & Activity & $\begin{array}{l}\text { Type of } \\
\text { impact }\end{array}$ & Impact significance \\
\hline & & $\begin{array}{l}\text { Higher } \\
\text { standard of } \\
\text { living for } \\
\text { farmers }\end{array}$ & $\begin{array}{l}\text { Farmers had a higher standard of } \\
\text { living. }\end{array}$ \\
\hline & & $\begin{array}{c}\text { Conflict of } \\
\text { irrigation } \\
\text { water } \\
\text { utilization }\end{array}$ & $\begin{array}{c}\text { There were conflicts of irrigation } \\
\text { water utilization. }\end{array}$ \\
\hline & $\begin{array}{l}\text { 2. Irrigation network } \\
\text { maintenance }\end{array}$ & $\begin{array}{c}\text { Well- } \\
\text { maintained } \\
\text { conditions of } \\
\text { irrigation } \\
\text { network and } \\
\text { supporting } \\
\text { facilities }\end{array}$ & $\begin{array}{l}\text { The level of damage to the } \\
\text { irrigation network and } \\
\text { supporting facilities during the } \\
\text { operation could be lower. }\end{array}$ \\
\hline
\end{tabular}

Source: Data Analysis (2020)

The above mentioned impacts require environmental management and monitoring efforts described in the matrices in Table 4 and Table 5.

Table 4. Matrix of Environmental Management Efforts

\begin{tabular}{|c|c|c|c|c|}
\hline \multirow{2}{*}{$\begin{array}{l}\text { Source of } \\
\text { Impact }\end{array}$} & \multirow{2}{*}{$\begin{array}{l}\text { Type } \\
\text { Impact }\end{array}$} & \multicolumn{3}{|c|}{ Environmental Management Efforts } \\
\hline & & \begin{tabular}{|l|} 
Form of Effort \\
\end{tabular} & Location & Period \\
\hline $\begin{array}{l}\text { Planning, } \\
\text { survey, and } \\
\text { measuremen } \\
t\end{array}$ & $\begin{array}{l}\text { Public } \\
\text { perception } \\
\text { and attitude } \\
\text { during the } \\
\text { activities }\end{array}$ & $\begin{array}{l}\text { - Giving notification of the } \\
\text { survey from the } \\
\text { development proponent } \\
\text { to the community } \\
\text { representatives } \\
\text { - Equipping the surveyors } \\
\text { with an authorized letter } \\
\text { of assignment } \\
\text { - Requiring the surveyors to } \\
\text { have the capability of } \\
\text { explaining the purpose of } \\
\text { the survey }\end{array}$ & $\begin{array}{l}\text { Surrounding } \\
\text { area of Tingal } \\
\text { Irrigation } \\
\text { Scheme }\end{array}$ & $\begin{array}{l}\text { Once during } \\
\text { the period of } \\
\text { planning, } \\
\text { survey, and } \\
\text { measurement }\end{array}$ \\
\hline
\end{tabular}




\begin{tabular}{|c|c|c|c|c|}
\hline \multirow{2}{*}{$\begin{array}{l}\text { Source of } \\
\text { Impact }\end{array}$} & \multirow{2}{*}{$\begin{array}{l}\text { Type of } \\
\text { Impact }\end{array}$} & \multicolumn{3}{|c|}{ Environmental Management Efforts } \\
\hline & & Form of Effort & Location & Period \\
\hline $\begin{array}{l}\text { Disseminati } \\
\text { on and land } \\
\text { acquisition }\end{array}$ & $\begin{array}{c}\text { Public } \\
\text { perception } \\
\text { and attitude } \\
\text { during the } \\
\text { activities }\end{array}$ & $\begin{array}{l}\text { - Conducting transparent } \\
\text { dissemination of } \\
\text { development plan from } \\
\text { the authority to the } \\
\text { potentially affected } \\
\text { residents } \\
\text { - Providing clear answers to } \\
\text { the questions from the } \\
\text { residents } \\
\text { - Inviting some residents as } \\
\text { the community } \\
\text { representatives in the } \\
\text { study area } \\
\text { - Conducting } \\
\text { participatory } \\
\text { acquisition process for the } \\
\text { affected landowners }\end{array}$ & $\begin{array}{l}\text { Surrounding } \\
\text { area of Tingal } \\
\text { Irrigation } \\
\text { Scheme }\end{array}$ & $\begin{array}{l}\text { Once during } \\
\text { the pre- } \\
\text { construction } \\
\text { period }\end{array}$ \\
\hline $\begin{array}{l}\text { Recruitment } \\
\text { of } \\
\text { construction } \\
\text { workers }\end{array}$ & $\begin{array}{l}\text { Job } \\
\text { opportunities } \\
\text { and business } \\
\text { opportunities }\end{array}$ & $\begin{array}{l}\text { - Prioritizing local workers } \\
\text { from the villages by } \\
\text { recruiting a minimum of } \\
50 \% \text { of them in order to } \\
\text { empower local human } \\
\text { resources } \\
\text { - Providing business } \\
\text { opportunities by allowing } \\
\text { the local residents to open } \\
\text { shops in the surrounding } \\
\text { area of the project } \\
\text { - Engaging in a direct } \\
\text { dialogue (deliberation) } \\
\text { with the members of } \\
\text { society surrounding the } \\
\text { construction site and } \\
\text { inviting community } \\
\text { leaders }\end{array}$ & $\begin{array}{l}\text { Surrounding } \\
\text { area of Tingal } \\
\text { Irrigation } \\
\text { Scheme }\end{array}$ & $\begin{array}{l}\text { During the } \\
\text { recruitment } \\
\text { process and } \\
\text { during each } \\
\text { development } \\
\text { activity }\end{array}$ \\
\hline
\end{tabular}




\begin{tabular}{|c|c|c|c|c|}
\hline \multirow{3}{*}{$\begin{array}{l}\text { Source } \\
\text { Impact }\end{array}$} & \multirow{2}{*}{$\begin{array}{l}\text { Type of } \\
\text { Impact }\end{array}$} & \multicolumn{3}{|c|}{ Environmental Management Efforts } \\
\hline & & Form of Effort & Location & Period \\
\hline & Social envy & $\begin{array}{l}\text { - Issuing open and } \\
\text { transparent } \\
\text { announcement about the } \\
\text { job vacancies } \\
\text { - Providing business } \\
\text { opportunities by allowing } \\
\text { the local residents to open } \\
\text { shops in the surrounding } \\
\text { area of the project } \\
\text { - Engaging in a direct } \\
\text { dialogue (deliberation) } \\
\text { with the members of } \\
\text { society surrounding the } \\
\text { construction site and } \\
\text { inviting community } \\
\text { leaders }\end{array}$ & $\begin{array}{l}\text { Surrounding } \\
\text { area of Tingal } \\
\text { Irrigation } \\
\text { Scheme }\end{array}$ & $\begin{array}{l}\text { During the } \\
\text { construction } \\
\text { period (during } \\
\text { the recruitment } \\
\text { process and } \\
\text { during each } \\
\text { development } \\
\text { activity) }\end{array}$ \\
\hline $\begin{array}{l}\text { Constructio } \\
\mathrm{n} \text { and } \\
\text { operation of } \\
\text { basecamp }\end{array}$ & $\begin{array}{l}\text { Public } \\
\text { perception } \\
\text { and attitude }\end{array}$ & $\begin{array}{l}\text { - Requiring the workers } \\
\text { who stayed in the } \\
\text { basecamp to maintain } \\
\text { cleanliness and display } \\
\text { clean and healthy life } \\
\text { behavior } \\
\text { - Maintaining good } \\
\text { relationships with the } \\
\text { local residents }\end{array}$ & $\begin{array}{l}\text { Surrounding } \\
\text { area of Tingal } \\
\text { Irrigation } \\
\text { Scheme }\end{array}$ & $\begin{array}{l}\text { During the } \\
\text { construction } \\
\text { period }\end{array}$ \\
\hline
\end{tabular}




\begin{tabular}{|c|c|c|c|c|}
\hline \multirow{3}{*}{$\begin{array}{l}\text { Source of } \\
\text { Impact }\end{array}$} & \multirow{2}{*}{$\begin{array}{l}\text { Type of } \\
\text { Impact }\end{array}$} & \multicolumn{3}{|c|}{ Environmental Management Efforts } \\
\hline & & Form of Effort & Location & Period \\
\hline & $\begin{array}{l}\text { Poor } \\
\text { environmenta } \\
\text { 1 sanitation }\end{array}$ & $\begin{array}{l}\text { - Providing basic sanitation } \\
\text { facilities (public bathing, } \\
\text { washing, and toilet } \\
\text { facilities) in the project } \\
\text { boundaries } \\
\text { - Managing waste and } \\
\text { placing trash bins in the } \\
\text { basecamp area } \\
\text { - Requiring the workers } \\
\text { who stayed in the } \\
\text { basecamp to maintain } \\
\text { cleanliness and display } \\
\text { clean and healthy life } \\
\text { behavior } \\
\text { - Implementing the Covid- } \\
19 \text { preventive health } \\
\text { protocol in the basecamp }\end{array}$ & $\begin{array}{l}\text { Irrigation } \\
\text { network of } \\
\text { Tingal } \\
\text { Irrigation } \\
\text { Scheme }\end{array}$ & $\begin{array}{l}\text { During the } \\
\text { construction } \\
\text { period }\end{array}$ \\
\hline $\begin{array}{l}\text { Mobilization } \\
\text { of } \\
\text { equipment } \\
\text { and } \\
\text { materials }\end{array}$ & $\begin{array}{l}\text { Higher levels } \\
\text { of dust } \\
\text { deposits and } \\
\text { exhaust gases }\end{array}$ & $\begin{array}{l}\text { - Tightly covering } \\
\text { soil/materials with truck } \\
\text { tarps during mobilization } \\
\text { - Scheduling mobilization } \\
\text { of equipment and } \\
\text { materials } \\
\text { - Sprinkling water on dry } \\
\text { areas of the project and on } \\
\text { the mobilization routes } \\
\text { every day at the beginning } \\
\text { and end of construction } \\
\text { hours } \\
\text { - Transporting materials at } \\
\text { working hours to avoid } \\
\text { public inconvenience, } \\
\text { such as during their } \\
\text { study, worship, rest, and } \\
\text { sleep time } \\
\text { - Scheduling } \\
\text { mobilization of equipment } \\
\text { and materials } \\
\text { - Limiting mobilization } \\
\text { activities from } 8 \text { a.m. to } 5 \\
\text { p.m. }\end{array}$ & $\begin{array}{l}\text { - Along the } \\
\text { access } \\
\text { routes/roads } \\
\text { to the } \\
\text { construction } \\
\text { site } \\
\text { - Surroundind } \\
\text { area of the } \\
\text { project } \\
\text { - Settlement } \\
\text { area and } \\
\text { irrigation } \\
\text { network area }\end{array}$ & $\begin{array}{l}\text { During the } \\
\text { construction } \\
\text { period }\end{array}$ \\
\hline
\end{tabular}




\begin{tabular}{|c|c|c|c|c|}
\hline \multirow{4}{*}{$\begin{array}{l}\text { Source } \\
\text { Impact }\end{array}$} & \multirow{2}{*}{$\begin{array}{l}\text { Type of } \\
\text { Impact }\end{array}$} & \multicolumn{3}{|c|}{ Environmental Management Efforts } \\
\hline & & Form of Effort & Location & Period \\
\hline & $\begin{array}{l}\text { Damaged } \\
\text { access roads } \\
\text { due to } \\
\text { overloaded } \\
\text { vehicles }\end{array}$ & $\begin{array}{l}\text { - Checking the load of } \\
\text { construction vehicles to fit } \\
\text { the capacity } \\
\text { - Directing the truck drivers } \\
\text { to be careful and adjust } \\
\text { the speed and tonnage } \\
\text { when passing potentially } \\
\text { damaged roads } \\
\text { - Paving the access roads to } \\
\text { improve the route } \\
\text { carrying capacity for } \\
\text { vehicle mobilization } \\
\text { - Repairing the damage to } \\
\text { the access roads }\end{array}$ & $\begin{array}{l}\text { - Access roads } \\
\text { to the } \\
\text { construction } \\
\text { site } \\
\text { - Along the } \\
\text { access } \\
\text { routes/roads } \\
\text { to the } \\
\text { construction } \\
\text { site }\end{array}$ & $\begin{array}{l}\text { During the } \\
\text { construction } \\
\text { period }\end{array}$ \\
\hline & $\begin{array}{l}\text { Potential } \\
\text { traffic } \\
\text { accidents }\end{array}$ & $\begin{array}{l}\text { - Installing warning signage } \\
\text { along the in-out access } \\
\text { roads of the project } \\
\text { boundaries and limiting } \\
\text { the vehicle speed } \\
\text { - Directing the truck drivers } \\
\text { to be careful and adjust } \\
\text { the vehicle speed }\end{array}$ & $\begin{array}{l}\text { - Along the } \\
\text { access } \\
\text { routes/roads } \\
\text { to the } \\
\text { construction } \\
\text { site } \\
\text { - In the } \\
\text { construction } \\
\text { site and } \\
\text { surrounding } \\
\text { area }\end{array}$ & $\begin{array}{l}\text { During the } \\
\text { construction } \\
\text { period }\end{array}$ \\
\hline & $\begin{array}{l}\text { Public } \\
\text { concern }\end{array}$ & $\begin{array}{l}\text { - Proactively making a } \\
\text { social approach to the } \\
\text { local residents to seek } \\
\text { viable solutions } \\
\text { - Installing warning signage } \\
\text { along the in-out access } \\
\text { roads of the project } \\
\text { boundaries and limiting } \\
\text { the vehicle speed }\end{array}$ & $\begin{array}{l}\text { - Along the } \\
\text { access } \\
\text { routes/roads } \\
\text { to the } \\
\text { construction } \\
\text { site } \\
\text { - In the } \\
\text { construction } \\
\text { site and } \\
\text { surrounding } \\
\text { area }\end{array}$ & $\begin{array}{l}\text { During the } \\
\text { construction } \\
\text { period }\end{array}$ \\
\hline
\end{tabular}




\begin{tabular}{|c|c|c|c|c|}
\hline \multirow{2}{*}{$\begin{array}{l}\text { Source } \\
\text { Impact }\end{array}$} & \multirow{2}{*}{$\begin{array}{l}\text { Type of } \\
\text { Impact }\end{array}$} & \multicolumn{3}{|c|}{ Environmental Management Efforts } \\
\hline & & Form of Effort & Location & Period \\
\hline \multirow[t]{2}{*}{$\begin{array}{l}\text { Land } \\
\text { developmen } \\
\mathrm{t}\end{array}$} & $\begin{array}{l}\text { Land-use } \\
\text { change }\end{array}$ & $\begin{array}{l}\text { - Performing selective } \\
\text { logging } \\
\text { - Compacting and } \\
\text { backfilling the canal } \\
\text { excavations when the } \\
\text { construction is completed } \\
\text { - Replanting flora/trees or } \\
\text { doing reforestation in the } \\
\text { surrounding area of the } \\
\text { land development after } \\
\text { the construction is } \\
\text { completed }\end{array}$ & $\begin{array}{l}\text { Irrigation } \\
\text { network area } \\
\text { of Tingal } \\
\text { Irrigation } \\
\text { Scheme }\end{array}$ & $\begin{array}{l}\text { During the } \\
\text { construction } \\
\text { period }\end{array}$ \\
\hline & $\begin{array}{l}\text { Disruption of } \\
\text { wildlife } \\
\text { habitat }\end{array}$ & $\begin{array}{l}\text { - Avoiding animal killing } \\
\text { - Removing bird nests or } \\
\text { animal burrows to a safe } \\
\text { place }\end{array}$ & $\begin{array}{l}\text { Irrigation } \\
\text { network area } \\
\text { of Tingal } \\
\text { Irrigation } \\
\text { Scheme }\end{array}$ & $\begin{array}{l}\text { During the } \\
\text { construction } \\
\text { period }\end{array}$ \\
\hline
\end{tabular}




\begin{tabular}{|c|c|c|c|c|}
\hline \multirow{2}{*}{$\begin{array}{l}\text { Source of } \\
\text { Impact }\end{array}$} & \multirow{2}{*}{$\begin{array}{l}\text { Type of } \\
\text { Impact }\end{array}$} & \multicolumn{3}{|c|}{ Environmental Management Efforts } \\
\hline & & Form of Effort & Location & Period \\
\hline $\begin{array}{l}\text { Developmen } \\
\mathrm{t} \text { activities }\end{array}$ & $\begin{array}{l}\text { Potential } \\
\text { occupational } \\
\text { accidents and } \\
\text { diseases }\end{array}$ & $\begin{array}{l}\text { - Registering the } \\
\text { construction workers for } \\
\text { BP Jamsostek (labor social } \\
\text { security program) } \\
\text { - Implementing } \\
\text { maximum of } 40 \text { working } \\
\text { hours per week and a } \\
\text { maximum overtime work } \\
\text { of } 7 \text { hours per week } \\
\text { - Installing construction } \\
\text { hoarding in the project } \\
\text { area w } \\
\text { - Installing workplace } \\
\text { safety signage (K-3) and } \\
\text { disseminating the signage } \\
\text { to the workers } \\
\text { - Facilitating and requiring } \\
\text { the workers to wear } \\
\text { personal protective } \\
\text { equipment (safety helmet, } \\
\text { boots, and mask) and to } \\
\text { work in accordance with } \\
\text { the standard operating } \\
\text { procedure } \\
\text { - Signing a statement of the } \\
\text { constructor's } \\
\text { accountability for all the } \\
\text { expenses arising out of } \\
\text { occupational accidents } \\
\text { - Implementing the Covid- preventive health } \\
\text { protocol }\end{array}$ & $\begin{array}{l}\text { Project } \\
\text { boundaries of } \\
\text { the irrigation } \\
\text { network area }\end{array}$ & $\begin{array}{l}\text { During the } \\
\text { construction } \\
\text { period }\end{array}$ \\
\hline
\end{tabular}




\begin{tabular}{|c|c|c|c|c|}
\hline \multirow{2}{*}{$\begin{array}{l}\text { Source of } \\
\text { Impact }\end{array}$} & \multirow{2}{*}{$\begin{array}{l}\text { Type of } \\
\text { Impact }\end{array}$} & \multicolumn{3}{|c|}{ Environmental Management Efforts } \\
\hline & & Form of Effort & Location & Period \\
\hline \multirow[t]{5}{*}{$\begin{array}{l}\text { Utilization of } \\
\text { irrigation } \\
\text { network }\end{array}$} & $\begin{array}{l}\text { Poor } \\
\text { environmental } \\
\text { sanitation }\end{array}$ & $\begin{array}{l}\text { - Installing "Do not litter" } \\
\text { signage around the } \\
\text { irrigation network area } \\
\text { - Functioning the irrigation } \\
\text { management and } \\
\text { regulatory institutions to } \\
\text { accommodate } \\
\text { environmental sanitation } \\
\text { issues } \\
\text { - Actuating the clean and } \\
\text { healthy life behavior } \\
\text { among the members of } \\
\text { society in the surrounding } \\
\text { area of the project } \\
\text { - Installing water depth } \\
\text { signage to prevent water- } \\
\text { related accidents }\end{array}$ & $\begin{array}{l}\text { } \\
\text { Irrigation } \\
\text { network area } \\
\text { of Tingal } \\
\text { Irrigation } \\
\text { Scheme } \\
\end{array}$ & $\begin{array}{l}\text { During } \\
\text { operation } \\
\text { period }\end{array}$ \\
\hline & $\begin{array}{l}\text { Increased } \\
\text { population of } \\
\text { aquatic biota }\end{array}$ & $\begin{array}{l}\text { - Spreading fish seeds } \\
\text { - Installing poison-fishing } \\
\text { and electrofishing } \\
\text { prohibition signage } \\
\text { - Prohibiting trash littering } \\
\text { along the irrigation canals } \\
\text { - Prohibiting waste disposal } \\
\text { to the irrigation canals }\end{array}$ & $\begin{array}{l}\text { Irrigation } \\
\text { network area } \\
\text { of Tingal } \\
\text { Irrigation } \\
\text { Scheme }\end{array}$ & $\begin{array}{l}\text { Periodic } \\
\text { management as } \\
\text { required }\end{array}$ \\
\hline & $\begin{array}{l}\text { Increased } \\
\text { population of } \\
\text { flora }\end{array}$ & $\begin{array}{l}\text { Prohibiting logging and } \\
\text { animal hunting/killing in } \\
\text { the surrounding area of the } \\
\text { project }\end{array}$ & $\begin{array}{l}\text { Irrigation } \\
\text { network area } \\
\text { of Tingal } \\
\text { Irrigation } \\
\text { Scheme }\end{array}$ & Bi-annually \\
\hline & $\begin{array}{l}\text { Higher } \\
\text { standard of } \\
\text { living for } \\
\text { farmers }\end{array}$ & $\begin{array}{l}\text { Providing education about } \\
\text { efficient and effective } \\
\text { utilization of irrigation } \\
\text { water }\end{array}$ & $\begin{array}{l}\text { Irrigation } \\
\text { network area } \\
\text { of Tingal } \\
\text { Irrigation } \\
\text { Scheme }\end{array}$ & $\begin{array}{l}\text { During the } \\
\text { operation } \\
\text { period }\end{array}$ \\
\hline & $\begin{array}{l}\text { Conflict of } \\
\text { irrigation } \\
\text { water } \\
\text { utilization }\end{array}$ & $\begin{array}{lrr}\text { Establishing an irrigation } \\
\text { management } & \text { institution, } \\
\text { such as } & \text { P3A, and } \\
\text { optimizing } & \text { irrigation } \\
\text { officers for } & \text { water } \\
\text { distribution } & & \end{array}$ & $\begin{array}{l}\text { Irrigation } \\
\text { network area } \\
\text { of Tingal } \\
\text { Irrigation } \\
\text { Scheme }\end{array}$ & $\begin{array}{l}\text { During } \\
\text { operation } \\
\text { period }\end{array}$ \\
\hline
\end{tabular}




\begin{tabular}{|c|c|c|c|c|}
\hline \multirow{2}{*}{$\begin{array}{l}\text { Source of } \\
\text { Impact }\end{array}$} & \multirow{2}{*}{$\begin{array}{l}\text { Type of } \\
\text { Impact }\end{array}$} & \multicolumn{3}{|c|}{ Environmental Management Efforts } \\
\hline & & Form of Effort & Location & Period \\
\hline $\begin{array}{l}\text { Irrigation } \\
\text { network } \\
\text { maintenance }\end{array}$ & $\begin{array}{l}\text { Well- } \\
\text { maintained } \\
\text { conditions of } \\
\text { irrigation } \\
\text { network and } \\
\text { supporting } \\
\text { facilities }\end{array}$ & $\begin{array}{l}\text { - Regularly monitoring the } \\
\text { fluctuation in water } \\
\text { volume and depth } \\
\text { - Making } \\
\text { inventory/recording data } \\
\text { of damage to the } \\
\text { irrigation network } \\
\text { - Relocating a specific } \\
\text { budget for maintenance } \\
\text { and repair of irrigation } \\
\text { network } \\
\text { - Carrying out regular } \\
\text { maintenance checks on } \\
\text { flap gates with regard to } \\
\text { the weather and lifespan } \\
\text { - Painting the facilities and } \\
\text { infrastructure buildings } \\
\text { - Periodically removing } \\
\text { trash and dredging } \\
\text { sediment Monitoring and and and and } \\
\text { evaluating the operation } \\
\text { and maintenance }\end{array}$ & $\begin{array}{l}\text { Irrigation } \\
\text { network area } \\
\text { of Tingal } \\
\text { Irrigation } \\
\text { Scheme }\end{array}$ & Annually \\
\hline
\end{tabular}

Source: Data analysis (2020)

Table 5. Matrix of Environmental Monitoring Efforts

\begin{tabular}{|l|l|l|l|l|}
\hline Source of of & Type \\
Impact & Impact & Environmental Monitoring Efforts & \\
\cline { 3 - 5 } $\begin{array}{l}\text { Planning, } \\
\text { survey, } \\
\text { and } \\
\text { measurem } \\
\text { ent }\end{array}$ & $\begin{array}{l}\text { Public } \\
\text { perception } \\
\text { and attitude } \\
\text { during the } \\
\text { activities }\end{array}$ & $\begin{array}{l}\text { Direct } \\
\text { observation } \\
\text { through interviews } \\
\text { with the members } \\
\text { of society }\end{array}$ & $\begin{array}{l}\text { Surrounding area } \\
\text { of } \\
\text { Irrigation Scheme }\end{array}$ & $\begin{array}{l}\text { Once during the } \\
\text { period of } \\
\text { planning, survey, } \\
\text { and } \\
\text { measurement }\end{array}$ \\
\hline $\begin{array}{l}\text { Dissemina } \\
\text { tion and } \\
\text { land } \\
\text { acquisition }\end{array}$ & $\begin{array}{l}\text { Public } \\
\text { perception } \\
\text { and attitude } \\
\text { during the } \\
\text { activities }\end{array}$ & $\begin{array}{l}\text { Interviews with } \\
\text { the members of } \\
\text { society }\end{array}$ & $\begin{array}{l}\text { Surrounding area } \\
\text { of Tingal } \\
\text { Irrigation Scheme }\end{array}$ & $\begin{array}{l}\text { Once during the } \\
\text { pre-construction } \\
\text { period }\end{array}$ \\
\hline
\end{tabular}




\begin{tabular}{|c|c|c|c|c|}
\hline \multirow{2}{*}{$\begin{array}{l}\text { Source of } \\
\text { Impact }\end{array}$} & \multirow{2}{*}{$\begin{array}{l}\text { Type of } \\
\text { Impact }\end{array}$} & \multicolumn{3}{|c|}{ Environmental Monitoring Efforts } \\
\hline & & Form of Effort & Location & Period \\
\hline \multirow[t]{2}{*}{$\begin{array}{l}\text { Recruitme } \\
\mathrm{nt} \text { of } \\
\text { constructio } \\
\text { n workers }\end{array}$} & $\begin{array}{l}\text { Job } \\
\text { opportunitie } \\
\mathrm{s} \quad \text { and } \\
\text { business } \\
\text { opportunitie } \\
\mathrm{s}\end{array}$ & $\begin{array}{l}\text { Inventory of } \\
\text { manpower and } \\
\text { local business } \\
\text { opportunities }\end{array}$ & $\begin{array}{l}\text { Surrounding area } \\
\text { of r Tingal } \\
\text { Irrigation Scheme }\end{array}$ & $\begin{array}{l}\text { During the } \\
\text { construction } \\
\text { period }\end{array}$ \\
\hline & Social envy & $\begin{array}{l}\text { Direct observation } \\
\text { and interviews }\end{array}$ & $\begin{array}{l}\text { Surrounding area } \\
\text { of } \quad \text { Tingal } \\
\text { Irrigation Scheme }\end{array}$ & $\begin{array}{l}\text { During the } \\
\text { construction } \\
\text { period }\end{array}$ \\
\hline \multirow[t]{2}{*}{$\begin{array}{l}\text { Constructi } \\
\text { on and } \\
\text { operation } \\
\text { of } \\
\text { basecamp }\end{array}$} & $\begin{array}{l}\text { Public } \\
\text { perception } \\
\text { and attitude } \\
\end{array}$ & $\begin{array}{ll}\begin{array}{l}\text { Direct } \\
\text { observation }\end{array} & \text { field }\end{array}$ & $\begin{array}{l}\text { The basecamp for } \\
\text { construction } \\
\text { workers' activities } \\
\text { and surrounding } \\
\text { area }\end{array}$ & \begin{tabular}{|l} 
During the \\
activities of the \\
construction \\
workers in the \\
basecamp \\
\end{tabular} \\
\hline & $\begin{array}{l}\text { Poor } \\
\text { environment } \\
\text { al sanitation }\end{array}$ & $\begin{array}{ll}\begin{array}{l}\text { Direct } \\
\text { observation }\end{array} & \text { field }\end{array}$ & $\begin{array}{l}\text { The basecamp for } \\
\text { construction } \\
\text { workers' activities }\end{array}$ & $\begin{array}{l}\text { During the } \\
\text { activities of the } \\
\text { construction } \\
\text { workers in the } \\
\text { basecamp }\end{array}$ \\
\hline \multirow[t]{3}{*}{$\begin{array}{l}\text { Mobilizati } \\
\text { on of } \\
\text { equipment } \\
\text { and } \\
\text { materials }\end{array}$} & $\begin{array}{l}\text { Higher levels } \\
\text { of dust } \\
\text { deposits and } \\
\text { exhaust } \\
\text { gases }\end{array}$ & $\begin{array}{ll}\begin{array}{l}\text { Direct } \\
\text { observation }\end{array} & \text { field }\end{array}$ & $\begin{array}{l}\text { Access roads to } \\
\text { the construction } \\
\text { site and along the } \\
\text { access } \\
\text { routes/roads to } \\
\text { the construction } \\
\text { site }\end{array}$ & $\begin{array}{l}\text { Once during the } \\
\text { construction } \\
\text { period }\end{array}$ \\
\hline & $\begin{array}{l}\text { Damaged } \\
\text { access roads } \\
\text { due to } \\
\text { overloaded } \\
\text { vehicles }\end{array}$ & 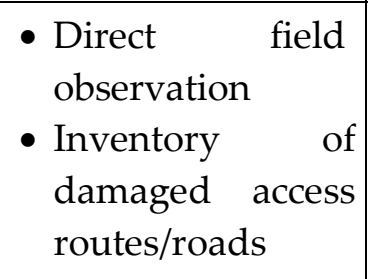 & $\begin{array}{l}\text { Access roads for } \\
\text { the mobilization of } \\
\text { equipment and } \\
\text { materials }\end{array}$ & $\begin{array}{l}\text { During } \\
\text { construction } \\
\text { period }\end{array}$ \\
\hline & $\begin{array}{l}\text { Potential } \\
\text { traffic } \\
\text { accidents }\end{array}$ & $\begin{array}{l}\text { - Direct field } \\
\text { observation } \\
\text { - Interviews with } \\
\text { the members of } \\
\text { society }\end{array}$ & $\begin{array}{l}\text { Access roads for } \\
\text { the mobilization of } \\
\text { equipment and } \\
\text { materials }\end{array}$ & $\begin{array}{l}\text { Once during the } \\
\text { construction } \\
\text { period }\end{array}$ \\
\hline
\end{tabular}




\begin{tabular}{|c|c|c|c|c|}
\hline \multirow{2}{*}{$\begin{array}{l}\text { Source of } \\
\text { Impact }\end{array}$} & \multirow{2}{*}{\begin{tabular}{|l|} 
Type \\
Impact
\end{tabular}} & \multicolumn{3}{|c|}{ Environmental Monitoring Efforts } \\
\hline & & Form of Effort & Location & Period \\
\hline & \begin{tabular}{l|} 
Public \\
concern
\end{tabular} & $\begin{array}{l}\text { - Direct field } \\
\text { observation } \\
\text { - Interviews with } \\
\text { the members of } \\
\text { society }\end{array}$ & \begin{tabular}{|l} 
Access roads for \\
the mobilization of \\
equipment and \\
materials
\end{tabular} & $\begin{array}{l}\text { During the } \\
\text { construction } \\
\text { period }\end{array}$ \\
\hline \multirow[t]{2}{*}{$\begin{array}{l}\text { Land } \\
\text { developme } \\
\text { nt }\end{array}$} & $\begin{array}{l}\text { Land-use } \\
\text { change }\end{array}$ & $\begin{array}{l}\text { Direct } \\
\text { observation }\end{array}$ & \begin{tabular}{|l|} 
Irrigation network \\
area of Tingal \\
Irrigation Scheme
\end{tabular} & $\begin{array}{l}\text { Once during the } \\
\text { construction } \\
\text { period }\end{array}$ \\
\hline & \begin{tabular}{|l|} 
Disruption of \\
wildlife \\
habitat \\
\end{tabular} & $\begin{array}{l}\text { Direct } \\
\text { observation }\end{array}$ & \begin{tabular}{|l|} 
Irrigation network \\
area of Tingal \\
Irrigation Scheme \\
\end{tabular} & $\begin{array}{l}\text { Once during the } \\
\text { construction } \\
\text { period }\end{array}$ \\
\hline $\begin{array}{l}\text { Developm } \\
\text { ent } \\
\text { activities }\end{array}$ & $\begin{array}{l}\text { Potential } \\
\text { occupational } \\
\text { accidents } \\
\text { and diseases }\end{array}$ & $\begin{array}{lr}\text { Direct } & \text { field } \\
\text { observation } & \\
\text { through interviews } \\
\text { and } \\
\text { examination } \\
\begin{array}{lr}\text { occupational } \\
\text { diseases } \\
\text { accidents }\end{array}\end{array}$ & $\begin{array}{l}\text { Irrigation network } \\
\text { area of Tingal } \\
\text { Irrigation Scheme }\end{array}$ & $\begin{array}{l}\text { Once during the } \\
\text { construction } \\
\text { period }\end{array}$ \\
\hline \multirow[t]{5}{*}{$\begin{array}{l}\text { Utilization } \\
\text { of irrigation } \\
\text { network }\end{array}$} & \begin{tabular}{|l|} 
Poor \\
environmental \\
sanitation \\
\end{tabular} & $\begin{array}{l}\text { Direct field } \\
\text { observation }\end{array}$ & \begin{tabular}{|l|} 
Irrigation network \\
area of Tingal \\
Irrigation Scheme
\end{tabular} & Annually \\
\hline & \begin{tabular}{|l|} 
Increased \\
population \\
of aquatic \\
biota \\
\end{tabular} & $\begin{array}{l}\text { Direct field } \\
\text { observation }\end{array}$ & \begin{tabular}{|l|} 
Irrigation network \\
area of Tingal \\
Irrigation Scheme
\end{tabular} & Bi-annually \\
\hline & $\begin{array}{l}\text { Increased } \\
\text { population } \\
\text { of flora }\end{array}$ & $\begin{array}{ll}\text { Direct } & \text { field } \\
\text { observation } & \end{array}$ & \begin{tabular}{|l|} 
Irrigation network \\
area of Tingal \\
Irrigation Scheme
\end{tabular} & $\begin{array}{l}\text { During the } \\
\text { utilization period }\end{array}$ \\
\hline & $\begin{array}{l}\text { Higher } \\
\text { standard of } \\
\text { living for } \\
\text { farmers }\end{array}$ & $\begin{array}{lr}\text { Interviews } & \text { and } \\
\text { direct } & \text { field } \\
\text { observation } & \end{array}$ & $\begin{array}{l}\text { Irrigation network } \\
\text { area of Tingal } \\
\text { Irrigation Scheme }\end{array}$ & $\begin{array}{l}\text { During the } \\
\text { utilization period }\end{array}$ \\
\hline & $\begin{array}{l}\text { Conflict of } \\
\text { irrigation } \\
\text { water } \\
\text { utilization } \\
\end{array}$ & $\begin{array}{l}\text { Institutional } \\
\text { assistance } \\
\text { direct } \\
\text { observation }\end{array}$ & \begin{tabular}{|l|} 
Irrigation network \\
area of Tingal \\
Irrigation Scheme
\end{tabular} & $\begin{array}{l}\text { During the } \\
\text { utilization period }\end{array}$ \\
\hline
\end{tabular}




\begin{tabular}{|l|l|l|l|l|}
\hline \multirow{2}{*}{$\begin{array}{l}\text { Imparce of } \\
\text { Impact }\end{array}$} & Type & Environmental Monitoring Efforts & \\
\cline { 3 - 5 } Impact & Form of Effort & Location & Period \\
\hline network & Well- & Observation and & Irrigation network & Annually \\
maintenan & maintained & inventory of & area of Tingal & \\
ce & irrigation of & damage to the & Irrigation Scheme & \\
& facilities & & \\
& network and & & & \\
& supporting & & & \\
& facilities & & & \\
\hline
\end{tabular}

Source: Data Analysis (2020)

The map of Environmental Management and Monitoring is presented in Figure 1.

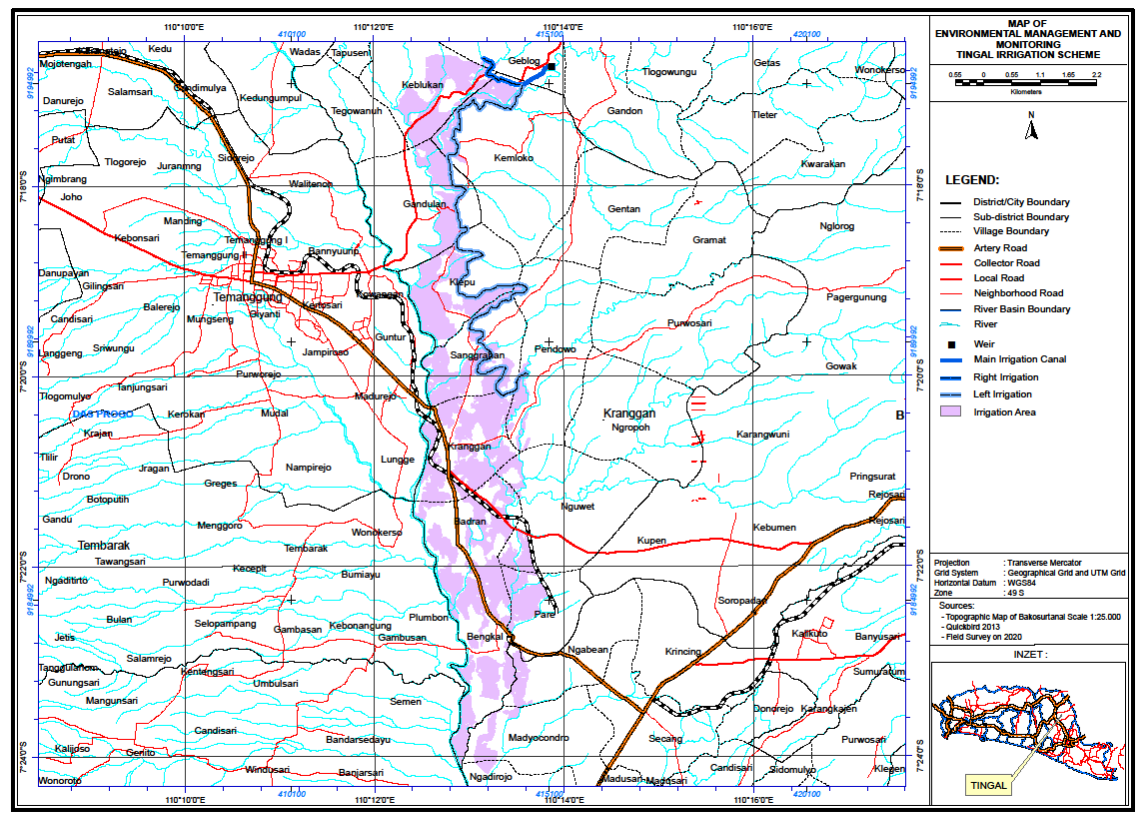

Figure 1. Environmental Management and Monitoring Map

\section{E. CONCLUSIONS}

The analysis results lead to the following conclusions: 1) The existing environmental conditions in the study area are generally of a good category; 2) The types of potential impacts in regard to the development project in the study area include: a) Planning, survey, and measurement: public perception and attitude during the activities; b) Dissemination and land acquisition: public perception and attitude during the activities; c) Recruitment of construction workers: job opportunities and business opportunities social envy; d) Construction and operation of basecamp: public perception and attitude poor environmental sanitation; e) Mobilization of equipment and materials: higher levels of dust deposits and exhaust gases: damaged access roads/routes due to overloaded vehicles potential traffic accidents public concern; f) Land development: land-use change, disruption of wildlife habitat; h) Utilization of irrigation network: poor environmental sanitation: increased population of aquatic biota, increased population of flora, higher standard of living for farmers, conflicts of irrigation water utilization; i) Irrigation network 
maintenance: well-maintained conditions of irrigation network and supporting facilities, Environmental management efforts should be made for each type of the potential impacts.

\section{ACKNOWLEDGEMENT}

The writer would like to acknowledge The Ministry of Public Work and PT. Karunia Sejahtera Consultan who have allowed me as the coordinator of the study.

\section{REFERENCES}

1. Al-Rumaihi, A., McKay, G., Mackey, H. R., \& Al-Ansari, T. (2020). Environmental impact assessment of food waste management using two composting techniques. Sustainability, 12(4), 1595.

2. Amato, A., Rocchetti, L., \& Beolchini, F. (2017). Environmental impact assessment of different end-of-life LCD management strategies. Waste management, 59, 432441.

3. BMKG (Meteorology, Climatology \& Geophysics Agency) of Semarang Climatological Station, Report of 2018.

4. Bogacka, M., Pikoń, K., \& Landrat, M. (2017). Environmental impact of PV cell waste scenario. Waste Management, 70, 198-203.

5. Cremiato, R., Mastellone, M. L., Tagliaferri, C., Zaccariello, L., \& Lettieri, P. (2018). Environmental impact of municipal solid waste management using Life Cycle Assessment: The effect of anaerobic digestion, materials recovery and secondary fuels production. Renewable Energy, 124, 180-188.

6. Decree of the State Minister for the Environment Number Kep-48/MNLH/11/1996

7. Deus, R. M., Mele, F. D., Bezerra, B. S., \& Battistelle, R. A. G. (2020). A municipal solid waste indicator for environmental impact: Assessment and identification of best management practices. Journal of Cleaner Production, 242, 118433.

8. Franks, D. M., \& Vanclay, F. (2013). Social Impact Management Plans: Innovation in corporate and public policy. Environmental impact assessment review, 43, 40-48.

9. García-Sanz-Calcedo, J., Al-Kassir, A., \& Yusaf, T. (2018). Economic and environmental impact of energy saving in healthcare buildings. Applied Sciences, 8(3), 440.

10. Gomiero, T., Pimentel, D., \& Paoletti, M. G. (2011). Environmental impact of different agricultural management practices: conventional vs. organic agriculture. Critical reviews in plant sciences, 30(1-2), 95-124.

11. Government Regulation No. 41/1999 on Air Pollution Control.

12. Government Regulation No. 82/2001 on Water Quality Management and Water Pollution Control.

13. Kaplan-Hallam, M., \& Bennett, N. J. (2018). Adaptive social impact management for conservation and environmental management. Conservation Biology, 32(2), 304314.

14. Law No. 32/2009 on Environmental Management and Protection. 
15. Li, Q., Liu, G., Leamon, G., Liu, L. C., Cai, B., \& Chen, Z. A. (2017). A national survey of public awareness of the environmental impact and management of CCUS technology in China. Energy Procedia, 114, 7237-7244.

16. Manik. (2003). Pengelolaan Lingkungan Hidup (Environmental Management). Jakarta: Djambatan.

17. Palmieri, N., Forleo, M. B., Giannoccaro, G., \& Suardi, A. (2017). Environmental impact of cereal straw management: An on-farm assessment. Journal of Cleaner Production, 142, 2950-2964.

18. Regulation of the State Minister for the Environment No. 16/2012 on the Guidelines for the Preparation of Environmental Documents.

19. Soemarwoto, Otto, 2004, Pengelolaan Lingkungan Hidup (Ecology, Environment, and Development), Jakarta: Djambatan.

20. Tayibi, H., Choura, M., López, F. A., Alguacil, F. J., \& López-Delgado, A. (2009). Environmental impact and management of phosphogypsum. Journal of environmental management, 90(8), 2377-2386.

21. Tiwary, R. K. (2001). Environmental impact of coal mining on water regime and its management. Water, Air, and Soil Pollution, 132(1), 185-199.

22. Yadav, P., \& Samadder, S. R. (2018). Environmental impact assessment of municipal solid waste management options using life cycle assessment: a case study. Environmental Science and Pollution Research, 25(1), 838-854.

23. Yilmaz, O., Kara, B. Y., \& Yetis, U. (2017). Hazardous waste management system design under population and environmental impact considerations. Journal of environmental management, 203, 720-731. 